\title{
Three years of change in college and
}

\section{university libraries}

\author{
Prepared by the National Center for Education Statistics \\ Washington, D.C.
}

\section{Academic library statistics from 1979 to 1982 reflect changes in holdings, budgets, staff, and usage.}

otal operating expenditures of college and university libraries increased by $30.4 \%$ between school years 1978-79 and 1981-82, while the inflation rate was $37.3 \%$ for the same period. Expenditure increases for salaries $(30.0 \%)$ were lower than the inflation rate, while expenditures for fringe benefits $(47.8 \%)$ exceeded the inflation rate. Total receipts from Federal Government grants decreased by $23.2 \%$ from 1979 .

These are some of the findings of a National Center for Education Statistics (NCES) survey of college and university libraries for the school year ending in $1982 .{ }^{1}$ The survey had a $91 \%$ response rate from a universe of 3,326 college and university libraries. Data were imputed for all nonrespondents with the exception of 89 institutions that were not in the 1979 survey. This report presents selected aggregates for the 50 states and District of Columbia and compares them with the last NCES survey of college and university libraries for the school year ending in 1979.

${ }^{1}$ All library data are reported with reference to academic years 1978-79 and 1981-82, except for library staff and student enrollment data which are reported as of fall 1979 and 1982, and library reference transactions which are reported as of spring 1979 and 1982.

\section{Holdings and acquisitions}

Total book volumes increased from 517.2 million in 1978-79 to 567.8 million in 1981-82 (Table 1). Although total book collections increased during this period, acquisitions of book volumes and titles decreased by $9.1 \%$ and $11.6 \%$, respectively, when comparing the two survey years (Table 2). This decline in book acquisitions continues the downward trend which began in 1972-73.

Periodical subscriptions, however, increased $3.0 \%$ (Table 2). The popularity of periodicals carried over into microforms, where the number of periodical titles available increased a substantial $58.3 \%$ over $1978-79$ (Table 1). Acquisition of periodicals on microforms was up $52.5 \%$ from 1978-79 to 1981-82 (Table 2). Audiovisual materials were being added at a slower rate, down $22.4 \%$ from 1978-79 (Table 2).

\section{Expenditures and receipts}

Operating expenditures in academic libraries increased by $\$ 452.9$ million or $30.4 \%$ from $1978-79$ to 1981-82 (Table 3). During the same 3-year period, the inflation rate, based on the Consumer Price Index, was $37.3 \%$. (The inflation rate is derived from monthly figures published by the $\mathrm{Bu}$ reau of Labor Statistics.) Thus, expenditures did not increase as fast as inflation. 
Table 1-Holdings of library materials, by type in college and university libraries: 50 States and D.C., 1979 and 1982

\begin{tabular}{lcrr}
\hline \multicolumn{1}{c}{ Holdings, by type } & $1978-79$ & $1981-82$ & \% change \\
\hline & \multicolumn{2}{c}{ (In thousands) } & \\
Book volumes & 517,152 & 567,826 & +9.8 \\
Book titles & 338,426 & 369,916 & +9.3 \\
Government documents (in separate collections) & 89,974 & 106,285 & +18.1 \\
Microforms - book titles & 39,094 & 46,631 & +19.3 \\
Microforms-periodical titles & 2,493 & 3,947 & +58.3 \\
Microforms-other & 223,502 & 307,443 & +37.6 \\
Audiovisual materials (titles) & 20,738 & 24,762 & +19.4 \\
All other library materials (titles) & 118,952 & 160,182 & +34.7 \\
\hline
\end{tabular}

Table 2-Acquisition of library materials, by type in college and university libraries: 50 States and D.C., 1979 and 1982

\begin{tabular}{lcrr}
\hline \multicolumn{1}{c}{ Acquisitions, by type } & \multicolumn{1}{c}{$1978-79$} & $1981-82$ & $\%$ change \\
\hline & \multicolumn{2}{c}{ (In thousands) } & \\
Periodical subscriptions & 4,749 & 4,890 & +3.0 \\
Book volumes & 21,460 & 19,507 & -9.1 \\
Book titles & 14,405 & 12,735 & -11.6 \\
Government documents (in separate collections) & 7,270 & 6,303 & -13.3 \\
Microforms-book titles & 3,275 & 3,054 & -6.3 \\
Microforms-periodical titles & 282 & 430 & +52.5 \\
Microforms-other & 21,609 & 26,375 & +22.0 \\
Audiovisual materials & 2,089 & 1,621 & -22.4 \\
All other library materials (titles) & 5,328 & 4,690 & -11.9 \\
\hline
\end{tabular}

Table 3-Operating expenditures and receipts of college and university libraries, by type: 50 states and D.C., 1979 and 1982

\begin{tabular}{lcrr}
\hline \multicolumn{1}{c}{ Expenditures and receipts, by type } & $1978-79$ & $1981-82$ & \% change \\
\hline \multicolumn{1}{c}{ Total library operating expenditures } & \multicolumn{2}{c}{ (In thousands) } & \\
Salaries and wages & $\$ 1,490,863$ & $\$ 1,943,769$ & +30.4 \\
Fringe benefits & 703,280 & 914,379 & +30.0 \\
Wages of students & 113,310 & 167,515 & +47.8 \\
Books & 79,086 & 100,847 & +27.5 \\
Periodicals & 223,207 & 255,767 & +14.6 \\
Microforms & 178,385 & 258,066 & +44.7 \\
Audiovisual material & 20,029 & 22,384 & +11.8 \\
All other library materials & 16,960 & 15,661 & -7.6 \\
Binding and rebinding & 9,174 & 9,321 & +1.6 \\
All other library operating expenditures & 25,176 & 30,351 & +20.6 \\
$\quad$ Total receipts from Federal Government & 122,256 & 169,478 & +38.6 \\
$\quad$ grants & & & \\
\hline
\end{tabular}

${ }^{1}$ Includes estimated value of contributed services.

${ }^{2}$ Serving on hourly basis. 
From 1978-79 to 1981-82, expenditures for library staff salaries increased $30.0 \%$, but expenditures for fringe benefits increased considerably more-up 47.8\% (Table 3). In 1981-82, the total expenditures for staff compensation (sum of salaries, fringe benefits, and wages for student assistants) of $\$ 1.2$ billion was just about double the amount spent on library material (sum of expenditures for books, periodicals, microforms, audiovisuals, and other library materials). In comparing the two survey years, the $47.8 \%$ increase in fringe benefits represents the largest percentage increase of any expenditures item, followed closely by the $44.7 \%$ increase of expenditures for periodicals. By comparison, expenditures for books increased by only $14.6 \%$. Indeed, 1982 total expenditures for periodicals exceeded total expenditures for books, $\$ 258.1$ million and $\$ 255.8$ million, respectively. Only one expenditure item showed a decreaseexpenditures for audiovisual materials was down $7.6 \%$. Total receipts from Federal Government grants showed a $23.2 \%$ decrease.

\section{Staff}

A total of 58,476 full-time equivalent (FTE) persons served on college and university library staffs in fall 1982, a $1.4 \%$ increase over fall 1979. This total represents approximately 155 FTE students per FTE library staff member in 1982, as compared with 147 FTE students per FTE library staff member in $1979 .^{2}$ Females represented approxi-

\footnotetext{
${ }^{2}$ Source of enrollment data: U.S. Department of Education, National Center for Education Statis-
}

mately $75 \%$ of the college and university library staff in both years. By contast, females represented only $52 \%$ of the college library administrators in 1982. Between 1979 and 1982 the number of female administrators increased by $6.9 \%$ while the number of male administrators decreased by $3.0 \%$.

\section{Library usage}

Although circulation of library materials was virtually unchanged-up $0.4 \%$, reference transactions increased substantially, up $64.8 \%$ since 1979 . In the spring of 1982 , reference transactions exceeded 1.6 million in a typical week. Interlibrary loans rose substantially; total loans to other libraries increased by $34.1 \%$ over 1979 , and loans from other libraries by $18.0 \%$.

\section{For more information}

The data used in this analysis is available from the National Center for Education Statistics (NCES). Inquiries about the data tape should be directed to the Statistical Information Office, National Center for Education Statistics, 400 Maryland Avenue N.W., (Brown Building, Room 606), Washington, DC 20202; (202) 254-6057.

For additional information about this report, contact Robert A. Heintze, Division of Multilevel Education Statistics, (202) 254-7351.

Editor's Note: This report has been reprinted from the NCES Bulletin for February 1984.

tics, Fall Enrollment in Higher Education 1979, and unpublished fall 1982 data.

\section{OMS selects ten ACRL members for its Institute on Research Libraries}

Twelve library school faculty have been invited to attend an Institute on Research Libraries July 9-27, sponsored by the Association of Research Libraries and operated by ARL's Office of Management Studies.

The three-week institute is being co-hosted by the University of North Carolina research libraries and the School for Library and Information Science, at Chapel Hill. It will encompass lectures, workshops, small group discussions, and a field experience in a major research library. Participants will be exploring the changes taking place in research libraries, and will be assessing the implications of those changes for library education.

The following ten of those selected are ACRL members: Robert N. Broadus, University of North Carolina School of Library Science; Terry A. Brooks, University of Iowa School of Library Science; Phyllis Dain, Columbia University School of Library Service; John N. DePew, Florida State
University School of Library and Information Studies; D.W. Krummel, University of Illinois at Urbana-Champaign Graduate School of Library and Information Science; William E. McGrath, State University of New York at Buffalo School of Information and Library Studies; Barbara B. Moran, University of North Carolina School of Library Science; Robert D. Stueart, Simmons College Graduate School of Library and Information Science; Thomas T. Surprenant, University of Rhode Island Graduate Library School; and Wayne A. Wiegand, University of Kentucky, College of Library and Information Science.

Also selected were Claire England, University of Toronto Faculty of Library and Information Science; and Renee Tjoumas, Catholic University School of Library and Inormation Science.

University administrators and research library directors will be involved in panel discussions during the final week of the event. 